\title{
Lendas galegas de ánimas
}

\author{
Camiño Noia Campos \\ Universidade de Vigo \\ cnoia@uvigo.es
}

\section{RESUMO}

O artigo ten como obxectivo presentar relatos sobre a volta das almas dos mortos ao mundo da realidade, que en Galicia son numerosos e, así mesmo, defender a súa adscrición ao xénero da lenda. Unhas historias conservadas no imaxinario popular ao longo dos séculos. Mediante a comparación co que sucede en países de cultura celta, en especial no norte e sur de Portugal e Bretaña que son os que mellor coñezo, interprétanse varios relatos de ánimas con diferentes motivos e axentes. Os temas esenciais céntranse na vinda ao mundo das ánimas para pedir favores elas soas. Cando veñen no grupo procesional da (Santa) Compaña é para penar os pecados e para avisar da morte dalgunha persoa da veciñanza. Saliéntase o sincretismo que existe neste tipo de textos entre os elementos da etapa celta, precristiá, e os inseridos pola doutrina católica sobre o purgatorio e o inferno desde a cristianización de Europa. A parte final do artigo dedícase a mostrar a amplitude do concepto de lenda no ámbito da folclorística e a defender a proposta do cambio de denominación dos relatos estudados atendendo á súa veracidade.

VERBAS CLAVE

Lendas; crenzas; Galicia; ánimas; cultura celta; cristianismo

\section{ABSTRACT}

The aim of the article is to present several stories about souls of the dead returning to the world of the living, stories which are numerous in Galicia, and to defend the view that they are connected with the genre of legends. The stories have been preserved in 
the popular imagination over the centuries. Stories of souls with different motifs and protagonists are interpreted by comparing them with other stories from countries of Celtic culture, especially Portugal and Britain, which are the ones I know best. The essential themes of these stories focus on the arrival of the souls in the world of the living in order to ask for favors. If they appear in a group, in the procession of the Compaña, then they have come back to the world to punish the living for their sins or to warn of the impending death of a neighbor. Of particular note in these types of text is the syncretism preserved between Celtic, pre-Christian elements and the subsequently introduced Catholic doctrine of purgatory and hell resulting from the Christianization of Europe. The final part of the article examines the broad nature of the concept of the legend in the field of folklore studies and proposes a change to the denomination of the stories on the basis of their veracity.

\section{KEYWORDS}

Legend; beliefs; Galicia; souls; Celtic culture; Christianity

\section{RESUM}

L'article té com a objectiu presentar relats sobre el retorn de les ànimes dels morts al món de la realitat, que a Galícia són nombrosos i, així mateix, defensar-ne la vinculació al gènere de la llegenda. Són unes històries conservades en l'imaginari popular al llarg dels segles. En comparació amb el que succeeix als països de la cultura celta, especialment al nord $i$ al sud de Portugal i a la Bretanya, que són els que conec millor, s'interpreten diversos relats d'ànimes amb diferents motius i agents. Els temes essencials se centren en l'arribada al món de les ànimes per sol-licitar els seus favors. Quan venen al grup processional de (Santa) Compaña és per castigar els pecats i advertir de la mort d'una veí. Es posa de relleu el sincretisme que existeix en aquest tipus de text entre els elements de l'etapa celta, precristiana, i els que s'insereixen en la doctrina catòlica sobre el purgatori i l'infern des de la cristianització d'Europa. La part final de l'article es dedica a mostrar l'amplitud del concepte de llegenda en el camp de la folklorística i defensar la proposta de canviar la denominació dels relats estudiats tenint en compte la seva veracitat.

PARAules CLAU

Llegenda; creences; Galícia; ànimes; cultura celta; cristianisme

REBUT: I2/O4/2OI9 | ACCEPTAT: I7/O6/20I9 
Es siempre el retablo de Ánimas uno a modo de gran cartelón de piedra, de forma cuadrilonga, rematando en extraño copete, que domina un monigote destinado a representar a Nuestra Señora. A sus pies una calavera humana, redonda como perilla de balcón y con más dientes que un caimán; debajo, dos tibias cruzadas; más abajo todavía un pajarraco con intenciones de figurar nada menos que la tercera persona de la Santísima Trinidad; y, por último, en el centro del cartel, las verdaderas protagonistas del drama, las Ánimas benditas.

Emilia Pardo Bazán, «El país de las benditas ánimas» (I887)

A sí describe Dona Emilia un dos moitos petos de ánimas que desde o medievo ata o século xx se construíron en encrucilladas e camiños de Galicia. E que xunto aos numerosas relatos de almas que volven ao mundo dan conta da fonda preocupación pola morte que caracteriza este país.

O pobo galego viviu unha realidade relixioso-cultural onde, como sucede en Bretaña, «tous parlent de mort, sujet de prédilection d'un peuple mystique», que di Dominique Besançon (I996: 84). Países nos que existe unha fonda solidariedade entre vivos e mortos, que non renacen, senón que volven á Terra para redimir os pecados e aliviar a pena, e por outras razóns.

As semellanzas entre as historias bretoas que Anatole Le Braz recolle en La légende de la Mort (I893) e as galegas, que adoitamos chamar crenzas, foi o estímulo para escribir este artigo que se pode considerar colectivo, en canto expón ideas de diferentes estudosos e transcribe relatos referidos na oralidade.

Son historias orixinadas nun pasado incerto por xente que habitou espazos sen luz, sen comunicacións e sen outra formación que a experiencia dos maiores que recibira das vellas tradicións a crenza na posibilidade de comunicarse cos mortos. E que no imaxinario colectivo do pobo se converteron en experiencia social, cultural e relixiosa, transmitíndose sen cambios de xeración en xeración ata mediados do século xx. Aínda hoxe podemos escoitarllas á xente maior de setenta anos.

\section{Sinais e visións da Morte}

No mundo rural galego, ata hai pouco máis de cincuenta anos, había a crenza de que cando unha persoa ía morrer un familiar ou veciño recibía un sinal, antes ou no mesmo momento da morte. Considerábanse sinais de morte: apagarse unha vela nun enterro, ver unha sombra detrás, ver ou oír grallar algún paxaro da morte (unha curuxa, un moucho, unha pega ou un corvo) enriba da casa de quen morre, oír ouvear un can ou cantar un galo pola tarde («cando o galo canta a deshora, o seu dono venta na cova» é un coñecido refrán) e alguna máis.

Unha variante do 'sinal' é a 'visión'; dicíase «ve-la visión», e consistía en ver a persoa viva no momento que morría lonxe de onde fora vista. Tense a visión no soño ou en vixilia, e só poden tela as persoas que no bautismo recibiron os Santos óleos.

Nos relatos presentados, a visión é de mortos na emigración e por accidente, sen que houbese un sinal previo... 
Unha muller da aldea mariñeira de Lira (A Coruña) conta o que lle sucedeu á súa nai e aos tíos cando eran pequenos. O pal, que fora carabineiro, emigrara a Buenos Aires e a muller quedou soa con tres fillos meniños. Unha noite, a nai déixaos sos na casa para ir a unha misión ${ }^{\mathrm{I}}$ e os nenos ven que alguén mete un brazo por un furado da porta; asustados péchana con chave e vanse deitar ao sobrado. Ao volver a nai, a porta estaba aberta, e os nenos cóntanlle o que sucedera; dinlle que a manga tiña os galóns como unha chaqueta de carabineiro e a nai non dubidou de que fora o marido que morrera na Arxentina. Pasados trinta días, chégalle unha carta dese país para informala da morte do home o mesmo día da visión dos fillos. A informante do suceso refíreo acreditando na veracidade dos feitos que a ela lle contaran a nai e a avoa.

No ano I99I, unha muller de oitenta anos de Sanxenxo (Pontevedra) contou, tamén como un suceso real, que unha cuñada súa vira a súa avoa que levaba quince anos morta, vestida de negro e de pé na cociña da súa casa. Olláronse as dúas sen dicir nada e a avoa saíu axiña pola porta. Por se viñera pedir oracións, a neta rezou pola súa alma. Días despois, espertou moi alterada ás tres da mañá sen saber por que; o fillo tivera un accidente de $\operatorname{coch}^{2}$ e morrera a esa mesma hora. Neste caso, a narradora e a súa cuñada entendían que a aparición da avoa fora para avisar da morte do mozo.

En Bretaña e en Portugal existe a mesma crenza de que cando morre alguén da veciñanza ou da familia, outra persoa recibe o aviso a través de les intersignes, unha especie de «ombre, projectée en avant, de ce qui doit arriver», ou por unha visión. E, como nas lendas galegas, «la personne à qui se manifeste l'intersigne est rarement celle que la mort menace» (Le Braz I893, ch. I). ${ }^{3}$

\section{Lendas de ánimas}

Sen máis cultura que a recibida na tradición oral, a xente das vellas comunidades rurais practicaron unha fe naturalista e de intensa comunicación cos defuntos. Os ámbitos de claro-escuros, creados polas tebras da noite e a frondosidade da natureza (mestas fragas, orografía penedosa, vento, mar bravo...), en especial de noite, eran propicias ás aparicións visionarias de ánimas. Así o mostran centos de lendas galegas, quizais porque, como di Antonio Fraguas (I986: I6-I7), «a noite préstase máis pra que ó redor das sombras e dos ruxidos do vento nas ponlas das carballas, a imaxinación popular poida entretecer as súas marabillosas lendas». O mesmo sinala Le Braz (I893: cap. II) para quen a noite é un dos elementos necesarios na aparición das âmes en peine: «Tant qu'il fait jour, la terre est aux vivants; le soir venu, elle appartient aux âmes défuntes. Les honnêtes gens font en sorte de dormir, toutes portes closes, à l'heure de revenants». ${ }^{4}$

I As misións eran unha especie de exercicios espirituais que se celebraban cada certo tempo nas igrexas parroquiais consistentes en escoitar en sermóns impartidos por predicadores de fóra, facer meditación, cantar e rezar. Duraba varios días.

2 Contouno na Aula da terceira idade de Vigo (Lembrazas de vellos 1993: 38).

3 O Capítulo I de La légende de la Mort está dedicado aos «Intersignes», e nos II e VI dáse máis información.

4 As referencias directas a autores bretóns e non aos doutras culturas celtas do norte de Europa débese a miña formación romanística. Os datos sobre a morte e as ánimas en Irlanda, Escocia e o País de Gales están recollidos, esencialmente, do investigador Fernando Alonso 
Estudosos da mitoloxía dos países atlánticos do norte, ${ }^{5}$ baseándose nas lendas irlandesas sobre o illote de «Tech Duinn», as do suroeste de Gales, as da illa de Green no oeste de Cornualles e as das Hébridas en Escocia (Alonso Romero 2009: 7-I3), afirman que os celtas crían na existencia da vida despois da morte, un mundo tan real como o dos vivos, pero máis gozoso. E a información sobre os mortos que transitan cara a illas tirada deses países Alonso Romero relaciónaa coa recollida por el na illa galega de Ons, ${ }^{6}$ situada na entrada da ría de Pontevedra. E comparando unhas lendas con outras non dubida en dicir que nas crenzas sobre a morte dos países atlánticos hai unha serie de elementos comúns de orixe celta e, entre outros, que o mundo dos mortos (O Alé) críase que estaba situado nunha illa do Atlántico, de límites imprecisos e espazos indefinidos. E tamén en Bretaña o folclorista bretón, Paul Sébillot (I983: I93), tomando a referencia do historiador bizantino Procopio (século vi d. C.), mostra a existencia dunha crenza bretoa de que as almas dos mortos viaxaban cara ao mar Atlántico.

Coa cristianización, as lendas celtas fóronse transformando ata chegar a delimitar o Alén no ceo e no inferno, aos que máis adiante se engade o purgatorio, ${ }^{7}$ lugares a onde irían os mortos segundo se comportasen na Terra. E ao longo da Idade Media a xente puido contemplar a representación deses lugares nas pinturas que cubrían as paredes das igrexas románicas e góticas coas que os clérigos adoutrinaban o pobo. Desa maneira, nun sincretismo difícil de xebrar no imaxinario popular entre as crenzas pagás e o dogma católico, creáronse as lendas de ánimas e dos revenants bretóns ${ }^{8}$ que chegaron a nós. Ánimas que proceden do purgatorio e, como explica o médico lugués Jesús Rodríguez López (I993: I66) a fins do século xix, poden aparecer en forma humana ou adquirir a de animais ou pedras:

Las almas de los muertos salen del Purgatorio para recordar los sufragios prometidos por las familias; unas veces se anuncian con quejidos dolorosos, otras se hacen preceder del ruido de cadenas con que están sujetas,

Romero, en especial do seu libro de 2009 sobre o mundo dos mortos en Galicia e no occidente europeo.

5 Alonso Romero (1981: 297) cita a obra de varios estudosos irlandeses, como: Proinsias MacCana (1970), Sean Ö Suilleabháin (1967), Thomas F. O’Rahilly (1976), etc.

6 Un territorio que pasou de 4I8 habitantes nos inicios do século xx a estar actualmente deserta durante o inverno e boa parte do outono (información de Alonso I98I). No verán abren dous restaurantes e habítanse algunhas casas.

7 Nunha carta do 6 de marzo de I254 enviada por Inocencio IV ao Legado da Sede Apostólica entre os gregos (Dezinger 456) cítase esplicitamente o nome 'purgatorium': «Nos, quia locum purgationis huiusmodi dicunt non fuisse sibi ab eorum doctoribus certo et propio nomine indicatum, illum quidem iuxta traditiones et auctoritates sanctorum Patrum Purgatorium nominantes volumus, quod de cetero apud ipsos isto nomine appelletur». («Xa que din que non foron informados do lugar desta purgación polos doutores con nome certo e propio, Nós, que de acordo coas tradicións e autoridades dos Santos Padres chamámolo purgatorio, queremos que de aquí en diante se chame con este nome tamén entre eles»). Quizais, baseándose nesta carta, Jacques Le Goff (I993: 433), un dos medievalistas máis recoñecidos, defende que a aparición do substantivo 'purgatorium' non é anterior ao derradeiro terzo do século XII. En castelán, a primeira aparición deste nome aparece en Berceo (Corominas I98I, sub voce 'puro'), e o primeiro rexistro en galego aparece nun documento de doazón de I444 (Maure 2006: 64).

8 «Selon une vielle croyance les âmes des trépassés ne quittent pas immédiatement la terre. Parfois, sans se faire voir, elles frappent aux portes la nuit pour réclamer messes et services» (Éveillard-Huchet 2004: 96). 
otras toman forma de piedras que se colocan en los caminos y que se quejan al ser pisadas [...] otras en visiones, otras en sueños; en fin, las almas de los muertos pueden, en la imaginación de las gentes tomar las formas más variadas y caprichosas.

\subsection{As ánimas en pena volven ao mundo}

Os motivos máis comúns que moven as ánimas a retornar ao lugar onde viviran están relacionados coa demanda de axuda na redención de penas no purgatorio, e son esencialmente tres: que digan misas por elas, que cumpran unha promesa que deixaran pendente e que repoñan o marco nunha leira. E xa que a motivación é, polo xeral, de tema relixioso, lévame a sospeitar que estas lendas máis que creacións espontáneas do imaxinario popular, puidesen ser creadas no púlpito para animar aos fregueses a facer doazóns á Igrexa e liberar as almas dos defuntos do purgatorio. Mais, resulta difícil distinguir o que é popular da elaboración clerical.

Os catro relatos que seguen están recollidos da oralidade no século xx. O primeiro nárrao o etnógrafo Antonio Fraguas (I973: I29) que non dá referencia do lugar do informante; os outros tres graváronse na década dos anos noventa nas provincias da Coruña, Ourense e Pontevedra. ${ }^{9}$

I. Días despois de morrer unha lavandeira, os veciños da aldea oen golpes no lavadoiro onde ela adoitaba lavar. Avisan o crego, e este, sospeitando que se trataba dunha ánima, foina requerir e informa ós veciños de que se trata da ánima da lavandeira que morrera e que viña penar no lugar onde pecara por lavar roupa os domingos. Pedía oracións para redimir os seus pecados de desobediencia á Igrexa. A veciñanza fixo as oracións e non se volveron oír os golpes.

A primeira vista, este relato semella de creación clerical para inducir aos fregueses a "gardar o día del Señor» (o domingo) sen traballar, como mandaba a Igrexa católica. Con todo, a figura dunha 'lavandeira' faime pensar na 'lavandière de nuit' das lendas bretoas da morte, "présentée comme une morte en pénitence pour faute professionnelle», segundo o folclorista bretón Dominique Besançon (I996: 97), quen a relaciona coa «petite fille des fées des fontaines» celta. Aventurando unha posible relación entre ambas lavandeiras dado que ambas son ánimas en pena (morte en pénitence), quizais a figura da galega teña reminiscencias na antiga deidade celta conservada na mitoloxía bretoa.

O segundo relato está narrado por un home de 54 anos das Pontes de Garcia Rodríguez (A Coruña), e conta o pedimento da ánima de que restitúan o marco que el sacara dunha leira.

2. Era unha vez unha familia que se dedicaban a cambiar marcos das fincas. - Hoxe chámanlles mojós, pero eran marcos- . E resulta que os andaban cambiando, arrincábanos. E un día foi un e arrincou un e tirouno nun pozo - Había alí un pozo moi fondo-. Ó pouco tempo o señor morreu. Morreu e volveu, volveu á vida. Entonces foi chamar alí un veciño que sabía que tiña peito, non. E díxolle:

9 Son textos inéditos polo que non damos a referencia bibliográfica. 
-Mira, sonche Manuel, non teñas medo. Tes que me vir facer un traballo.

-E que traballo?

- Mira, arrinquei un marco alí da finca de Antón e téñoo que volver poñer alí. E tireino nun pozo. E se non, non podo entrar no ceo.

- Pois a ver logo. Ha ter moita agua — dixo.

-Non che pasa nada, eu xa che direi onde está. E tu falo.

Entonces foron para alí e díxolle:

-Mira!, estache aí.

E o bon do home non se mollou nin nada. Agarrou, meteuse alí, colleu a pedra e volveuna poñer na finca onde estaba. E, bueno, ó outro día dixo que tiña musgo, herba, como se non se quitara d'alí.

O terceiro relato sitúase nunha aldea de Poio (Pontevedra) e refírese á aparición da ánima dun crego.

3. Antes de morrer, unha muller deixoulle cartos ó cura para que lle fixese misas; a muller morreu e o cura non llas fixo. A xente da aldea sabíao e cando morre o cura dicían que o vían polos camiños, cando viñan do muíño ou de bota-la auga; e case sempre iba cun can negro. Dicíase que se seguiría vendo a súa ánima ata que outro cura dixera as misas por el.

Aquí, a xente da veciñanza, coñecedora do asunto das misas que non dixera, ve a ánima en distintos lugares e ocasións e, parece que toda supón que o crego vén pedir que llas diga outro, mais a súa ánima non di nada. O can negro que a acompaña pode ser unha reminiscencia de orixe precristiá da representación da ánima, quizais por estar condenada, unha figura que tamén existe en Bretaña e en países celtas (Cuba et alii I999: 70-7I).

No cuarto relato, a ánima deixara unha promesa incumprida. É dunha muller de 50 anos da Gudiña (Ourense).

4. Morreu unha señora que tiña tres fillos e deixoulles un prado grande cunha poza, pero os fillos non podían ir alí porque tiñan medo dun ruído que sentían. E un deles dixo: «Pois hoxe eu vou saber o que é». Se conoce que o cura lle dixo que lle requerira (preguntase) a aquel ruído a ver si alguén lle falaba. Entonces foi e requeriulle que a ver si era unha cousa de Outromundo, que a ver que lle facía falta, que todo o que necesitara el llo faría. Ela [a ánima] díxolle: «Non me teñas medo, que son túa mai, namais te quero que lle compres un manto á Virgen e llo poñas, que llo tiña ofrecido eu». I el foise á casa e montou nun cabalo e marchoulle por el a Verín.

Julio Camarena e Maxime Chevalier (2003), quizais atendendo ao carácter folclórico que teñen hoxe este tipo de historias, clasifícaas como contos no seu Catálogo de cuentos españoles co subtipo 760E: «Ánima en pena hasta la restitución de lo robado». Non as inseriron, en cambio, no Catálogo de contos portugueses Isabel Cardigos e Paulo Correia (2OI5) e tampouco está no de contos galegos (Noia, 20IOa), por considerar que se trata dunha lenda.

Ademais dos motivos anteriores, as ánimas poden retornar ao mundo para axudar a familia. E, neste caso, o encontro entre as ánimas e familia pode situarse nun espazo interior e en horario diúrno. Así o vemos nos tres relatos que seguen, 
dous recollidos na provincia de Pontevedra (Fraguas I93I: 43); do terceiro non se di o lugar (Mariño i995b: 96):

I. Días despois de morrer, un vello avó volve á casa para axudar ós netiños a xuntar leña. Os nenos coñéceno e dinllo á nai. Ela pregúntalle que roupa levaba e confirma que era o avó ó recoñecer o hábito e o broche co que fora enterrado. A filla supón que o pai viñera pedir misas e págallas ó crego.

2. Enviuvou un pai e quedou só cuns fillos pequenos. Pola mañá ía cedo traballar no campo e deixaba os meniños na cama. Cando volvía á casa atopábaos erguidos e vestidos. Os nenos dicíanlle que era a nai, que morrera, quen os atendía. O pai acordou quedar agochado na casa para ver quen era, e viu a súa muller; achegouse a ela para agradecerlle o que facía, pero ela afastouse dicíndolle: «Agora víchesme, non podo tornar máis». ${ }^{\text {Io }}$

3. Mentres estaba un neno coas ovellas no monte fíxose noite e comezou a chover. Perdeuse e tiña medo do lobo e botouse a chorar. Cando ergueu a cabeza, viu un home cun bastón que lle dicía por onde debía ir. Seguiuno ata chegar preto da casa e deuse conta de que era o seu avó que morrera. Chamou por el, pero o avó desapareceu.

Esta variedade de lenda de ánimas resulta aínda máis suxestiva que as anteriores, pois as visións non son producidas por interese, nin polos remorsos dos vivos respecto aos mortos, senón que expresan o desexo de continuar mantendo a axuda dos seus familiares falecidos. E móstrannos a capacidade de suxestión da xente de sinxela que lle atribúe veracidade a un suceso visionario, quizais pola intensidade do sentimento de que as cousas sucedesen así.

Sen dúbida, a concepción visionaria do Alén e a crenza na comunicación coas ánimas era tan grande na xente das vellas comunidades que, de precisaren algo delas, íanas buscar. E facíano, esencialmente, por dous motivos: para que lle sacasen o 'aire' (asombramento) que lle deixaran a un neno que non medraba ou a un adulto que perdía forzas ou para que lle dixesen onde gardaran os cartos que o vivo lles deixara en depósito. Nestes casos, unha persoa, acompañada, ou instruída por un crego, ía requerir ${ }^{\text {II }}$ a ánima á sepultura ás doce da noite, chamala tres veces e á terceira era cando respondía. Se era para sacar o aire, había que dicir a letanía: «Sácame o aire do morto e dáme o do vivo. Aire de morto non ten conforto, o do vivo é confortativo».

O relato que segue é dun mozo que vai buscar unha morta para recuperar uns cartos. Contouno unha muller de 58 anos da Gudiña (Ourense) na década dos anos noventa:

Era un rapaz que gañou trinta duros servindo. E cando tivo que ir ao Servicio foille levar os cartos ao cura, pero este díxolle que era mellor que llos dera á señora María. Pois se ela morría, podíalle responder deles a filla. O rapaz fixo o que lle dixo o crego. A señora María morreu e cando volveu do Servicio, preguntoulle á filla polos trinta duros. Ela non sabía nada diso. O cura aconselloulle ao rapaz que fose de noite a unha encrucillada,

Io Un relato semellante a este, haino na antoloxía de Mariño (I995b: 94-95).

II Ese verbo é específico desa función, e significa ir chamar por un defunto, en ocasións, utilizando unha fórmula ou pregaria. 
e cando sentise o ruído da Compaña que chamara tres veces pola señora María. A primeira noite que foi non lle respondeu. O cura mandouno ir de novo e volver chamar tres veces pola señora. Daquela, a defunta respóndelle e dille que os cartos están «na soleira da cuciña [...] metidos nun xustillo vello». E alí os atopou a filla.

Estoutro, tamén da provincia de Ourense, recolleuno Antonio Fraguas (I93I $b$ : 224), en Armeses, no concello de Maside, no primeiro terzo do século pasado. Aquí, ademais de dicirlle onde están os cartos, a ánima dille ao vivo onde está ela e dálle un aviso para o tío de ambos:

Un home dálle os aforros á unha irmá para que llos garde. A muller morre, aos poucos días, unha sombra persegue o irmán «dándolle grima ao mirar pra ela». Un tío crego dille que vaia requerir a irmá que quizais fose ela que viña acompañalo ao mundo. Pola noite foi cos brazos en cruz ao camposanto para requerila. Ao pouco, o home oíu uns pasos e ve un bando de almas que pasaban rezando. Pregunta por ela e dinlle que vai atrás. Cando a ánima atopa o irmán, dille que os cartos están nunha trabe da casa e, engade que ela está no inferno e non pode ver a cara de Noso Señor, e que lle diga ao tío cura que como non deixe de murmurar ${ }^{\mathrm{I2}}$ e cambie de vida, hai unha cama no inferno agardando por el. A sombra desapareceu e o irmán morreu aos tres meses.

As dúas historias son semellantes no motivo e no modus actuandi, a ánima sae da sepultura coa Compaña (da que falarei máis adiante) e os vivos atópana cando van preguntar polos cartos que lle deixara á defunta. Nesta, a ánima confesa que está no inferno, o que incumpre a doutrina da Igrexa que instituía o inferno como lugar do que non era posible saír. Unha figura que está presente nestoutro relato de ánimas, tamén da colección de Fraguas (I93I: 43-44), unha variante da anterior cos outros motivos. A ánima dunha esposa, que se comunica cos vivos, vén acompañada do home que está condenado no inferno e non pode falar, dise:

Días despois de morrer, un matrimonio aparece preto da súa casa; os veciños vanos requerir «en nome de Deus, de San Pedro e de San Pablo...» e a muller responde: «Eu estou en bo lugar (suponse que no purgatorio), pero o meu home condenouse porque tiña pensado matarse e, agora, se fala, bota lume pola boca».

O motivo de botar lume pola boca está relacionado co da lenda da «Raposa do Morrazo» (Pontevedra) e do «Animal de Murillas» de Padrón na provincia da Coruña (Fraguas I93I: 44); exemplos aos que se poden engadir máis, como o da «Raposa facheira», da «Cadela peregrina» ou do "Cabalo pantasma» do norte de Lugo, que a xente identifica cunha alma condenada que anda desacougada polos montes botando lume. Unha figura que tamén existe na tradición bretoa considerada garda das portas do Paraíso (Besançón I996: 97-IO2), na irlandesa e na rexión portuguesa do Algarve onde se coñece como «A zorra berradeira» ou «de Odelouca» ${ }^{\mathrm{I} 3}$ (Consiglieri Pedroso I980: 204). En igrexas galegas de arte románica

I2 Unha cantiga popular fai referencia a isto: «Marmula, marmulador, / marmula de min e doutro / no inferno hai unha cama / para descansar un pouco».

I3 O Algarve portugués non é un país de orixe celta. Os motivos e temas que ten na súa tradición oral atribuídos á cultura celta, como a lenda da alma condenada en figura de ra- 
hai esculpidas en canzorros dos muros exteriores e en capiteis de entrada, nunca no interior da igrexa, figuras de cans botando lume pola boca, que estudosos da arte románica adoitan describir como dragóns. Non poderían ser figuras simbólicas gardadoras do paraíso conservadas da cultura celta?

\subsection{Tamén volven os condenados}

Relacionada co antigo costume de amortallar os defuntos cun hábito bendecido para impedir que vaian ao inferno, documentado desde o século Xıx (Fraguas I93I: 42), debeu xurdir a lenda do condenado que se aparece de noite en camiños e encrucilladas a un home e pídelle axuda para poder ir descansar ao inferno, impedido de acougar en sitio ningún. A lenda baséase en que se a un defunto que está en pecado mortal lle poñen un hábito bendito (unha sotana de ser crego), non podería ir ao inferno, pero tampouco ao purgatorio nin ao ceo. De maneira que, no imaxinario popular (quizais tamén nas predicas dos cregos), créase a lenda de que andaría desacougado por camiños e encrucilladas ata desprenderse do hábito. E, como non podía facelo coas súas mans, buscaba un home mozo que llo rachase. Nesta lenda, a diferenza das anteriores, o condenado (sempre varón) non se considera ánima, chámaselle 'fantasma', 'aparecido' ou, simplemente, 'home'. E tamén aquí a lóxica narrativa rompe coa do dogma católico de que as almas dos condenados van directamente ao inferno.

Esta versión de Fraguas (I93I: 43), que el oíra contar na súa adolescencia en Loureiro de Cotobade (Pontevedra), reúne todos os motivos da lenda:

Unha noite nunha encrucillada, un mozo atopa unha pantasma e suplícalle que lle rache o hábito. O mozo descúlpase, mais a pantasma, que era unha ánima, porfía en que llo faga. O mozo non accede e vai onda o crego contarlle o sucedido. O crego dálle unha estola cun crucifixo e dille que non teña medo que ninguén lle fará mal. A ánima volve á encrucillada e dille: «Hoxe vés preparado e tes que racharme o hábito». O mozo quere saber quen é, ela non llo quere dicir, mais logo dillo e explícalle como ten que facer para romperlle o hábito. O mozo ráchallo cunha fouce e, de súpeto, ábrese un bocarón enorme no chan no que o morto se afunde no medio dunha forte labarada e fumareda e facendo un longo bruído. $\mathrm{O}$ mozo morre ao pouco tempo porque o morto era amigo seu.

O condenado é unha 'pantasma', aclarando que se trata dunha ánima. Como noutras versións, o crego dálle uns obxectos litúrxicos ao mozo para defenderse do demo, mais podería mándalle facer un círculo ${ }^{\mathrm{I} 4}$ e meterse dentro ou dicir unha oración laudatoria a Deus e contra o mal. A descrición da abertura dun enorme burato (bocarón) polo que sae lume e fume no momento de romperlle o hábito ao condenado é moi plástica e repítese tamén noutras versións.

posa errante, foron levados polos poboadores do norte de Portugal na colonización do sur despois da expulsión dos árabes. O nome de Odelouca é o do río que rega unha ampla zona do Algarve onde a lenda ten moita presenza, mais tamén existe noutros lugares do Algarve como nos concellos de Lagos, Silves e Monchique (Neves Casinha Nova 20I2: III).

I4 A simboloxía do círculo vén do disco solar. O sol, como creador da luz y dono da vida nas etapas precristiás, no cristianismo simboliza o eterno e absoluto, Deus en definitiva, que dá protección. 
Para Rodríguez López (I993: I70) esta lenda é unha «superstición importante» do pobo galego; con todo, refire en castelán unha versión que lle contaron na que o condenado é un usureiro que se lle aparece a un mozo no adro da igrexa botando lume pola boca, que remata do mesmo xeito ca anterior: «tan pronto fue terminado el corte, se abrió la tierra y tragó al difunto usurero, entre llamas de fuego y una pestilente humareda de azufre». O cheiro a xofre, que forma parte da representación do inferno co lume queimando condenados, reitérase noutras versións da lenda. Unha recollida na provincia da Coruña (Quintáns 20o6: 64-65) difire das demais en que o defunto non sae da sepultura, chama polo fillo desde a cova para que o desenterre e lle rache o hábito: «Meu filliño, axúdame! Se non me desenterras e me libras do hábito que levo posto no podo entrar no inferno e estou a pasalo moi mal», dille. O mozo non o fai e vai preguntarlle ao crego, que lle di como debe actuar. O mozo desenterra o pai, córtalle o hábito e veo afundirse na terra cheirando tamén a xofre.

Esta lenda está clasificada como conto relixioso co tipo $760 \mathrm{~B}$ no Index de contos folclóricos españois do norteamericano Ralph Boggs (I930), en cambio, non a rexistra Arnee-Thompson (I96I), que recolle tipos dese índice na última edición do catálogo de Types of International Folktales, nin Jörg Uther na revisión de 2004. Si está no Catálogo de contos españoles de Camarena-Chevalier (2003) que rexistra versións en varias provincias do norte peninsular (Asturias, León, Vizcaya e Huesca na área do catalán) así como en América latina; e tamén a teño rexistro eu no Catálogo tipolóxico do conto galego (Noia 20Ioa) coa referencia de oito versións.

\section{A (Santa) Compaña}

Nos relatos que vimos ata agora as ánimas aparecían esencialmente en solitario; na lenda da Compaña, en cambio, as ánimas veñen en procesión ao mundo real, avisando de mortes próximas. Unha procesión que tamén existe en Asturias co nome de Huestia (La Buena gente), na mitoloxía irlandesa, coñecida como a hoste dos Sides, e en Bretaña, na representación do Ankou, o obreiro da morte («oberour ar maro»), aínda que neste caso sae el so recoller os defuntos. Neses países, os compoñentes da Huestia e o Ankou, con diferentes procedementos, tiñan a misión de vir buscar xente das aldeas que ía morrer e levala ao Alén ou mundo dos mortos.

A Compaña recibe en Galicia nomes diferentes: Compaña (Santa), Compañía, Procesión das ánimas, Estadea, Hoste, Visita, Visión, Acompañamento, etc. ${ }^{15}$

As primeiras referencias á lenda, segundo o antropólogo aragonés Lisón Tolosana (I998: I9-20), aparecen en documentos da Inquisición dos séculos XVI e XVII, considerada unha superstición castigada polo tribunal español desta cruel institución.

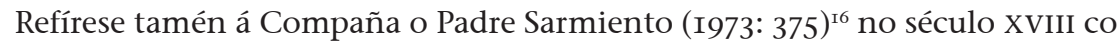
nome de procesión de jans, xaira e ostea pero non a describe, só di: «Dícese hacia

I5 Sobre a nomenclatura da Compaña, os axentes que participan nela, o trato que teñen, os modos sensoriais de vela, o espazo, o tempo e os motivos da saída dá abundante e pormenorizada información Lisón Tolosana (I998: I45-I49).

I6 Catálogo de voces y frases de la lengua gallega, I745, folio I63r (Sarmiento I973: 375). Sobre as 'xans' ou 'xas' pódese consultar Cuba et alii. I999. A figura das xans (xas), nomes tirados de relatos da oralidade, ten diferentes interpretacións, mesmo na obra de Lisón Tolosana (I998). Vide os capítulos terceiro, cuarto e quinto do libro sobre a Compaña. 
Orense fulano vio as jâns, y es lo mismo que ver la compaña o hueste». No século xix temos rexistradas varias referencias á lenda en textos de escritores, ${ }^{17}$ viaxeiros e médicos. O inglés George Borrow (I843), que viaxa por Galicia entre os anos I835-37 vendendo biblias, conta nas súas memorias que o guía que o acompañaba de Muros á Concurbión (A Coruña) lle falara da Estadea. Foi unha tardiña, pouco antes de se poñer o sol, cando pasaban por un páramo para advertilo de que era mellor deterse antes de anoitecer, pois se viña a brétema podían atopar a Estadea. Á pregunta de Borrow sobre que era iso, respondeulle:

Atopei coa Estadeíña unha vez e foi nun páramo algo semellante a este. Ía na compaña de varias mulleres, veu unha brétema espesa, supetamente un milleiro de luces brillaron na brétema sobre as nosas cabezas e houbo un berro salvaxe; e as mulleres caeron polo chan exclamando estadea! estadea! E eu mesmo caín polo chan a berrar, Estadeíña! A Estadea son as almas dos mortos que camiñan sobre da brétema portando candeas nas mans (Borrow I993: IO2-IO2).

O médico lugués Rodríguez López (I993: I67) considera a Compaña unha das varias supersticións do pobo galego das que fala no seu libro e descríbea como a visión dunha procesión de defuntos que ás doce da noite se levantan das tumbas e saen en ringleira atrás dun home vivo que vai cunha cruz sen poder virar a cabeza. Un dos defuntos leva un caldeiro con auga bendita e os demais levan luces que poden non ser visibles para os humanos; nese caso, a presenza da Compaña notaríase polo olor de cera ardendo. A procesión adoita rematar na porta da casa dun veciño anunciando a súa morte e deixándolle un cadaleito ou botándolle pedras no tellado. O vivo que vai coa cruz só pode librarse dela se atopa alguén a quen darlla. E para evitalo, a persoa que atopa a Compaña debe facer algunha destas cousas: poñer os brazos en cruz, cruzalos no peito e dicir «cruz teño», ter as mans ocupadas, levar amuletos no peto (allos, escapularios, cornos de insectos...), deitarse no chan boca abaixo ou facer un círculo cunha cruz ou a estrela de Salomón e meterse dentro. Nunha breve definición, a Compaña é unha procesión formada por ánimas de defuntos chamadas estadeas (estántigas, dicían os meus ancestros), de contido e formas imprecisas e diversas. ${ }^{18}$

As diferentes versións que se contan da lenda da Compaña son moi variadas, o mesmo que sucede coas de ánimas soas. Trátase de figuracións visionarias que a través da transmisión oral chegan ao imaxinario colectivo como sucesos nos que a xente acredita e refai ao seu gusto.

$\mathrm{Na}$ Galicia de hai menos de cen anos, a xente do rural tiña terror a andar de noite polos camiños, non só polo ataque de lobos e ladróns, senón pola posibilidade de topar a Compaña e que un home acabase collendo a cruz do vivo, ou que unha das ánimas lle entregase unha vela (neste caso podía ser tamén a unha mu-

\footnotetext{
I7 No conto «Cometerra» de Emilia Pardo Bazán a vella protagonista explícalles aos netos que é a Compaña, Rosalía Castro refírese a ela no poema «Eu por vós e vós por outro» e Manuel Curros Enríquez, Francisco Añón e Victoriano Novo compoñen longos poemas sobre a procesión das ánimas.

I8 Antonio Fraguas (I990: 54) di algo moi curioso sobre os compoñentes da Compaña: «Es creencia general de que los que van en la Compaña solo van en espíritu, su cuerpo queda en cama y aun cuando lo llamen no responde. Todos los componentes tienen que guardar riguroso secreto». Segundo isto, parece que se cría que non eran mortos, senón que se trataba dos espíritos de xente viva.
} 
ller), que era en realidade un óso, e que significaba que a súa morte estaba próxima. Nese caso, di Vicente Risco (I962: 425-428), o individuo «ponse fraco, mírrase, perde a cor, síntese mal, anda tristeiro e amorriñado, quéixase de cansazo, que non pode consigo. Ponse marelo como a cera, «cor de defunto» e, moitas veces, non tarda en morrer», e dá unha versión da Compaña semellante á de Rodríguez López:

De noite, os defuntos érguense nas tombas e axúntanse na eirexa parroquial [...] o primeiro que se levanta é o que leva máis tempo enterrado; iste chama polos demais: «Levantaivos, defuntos, e saí todos xuntos!». Ó dar as doce saen pola porta principal levando a cruz procesional e a caldeireta de auga benta co hisopo. Asegún a versión máis constante, a cruz tena que levar unha persoa viva. Algunhas veces din que ten que ser un home, se o santo patrón da parroquia é varón [...] e unha muller se é santa [...]. Unhas veces, o mesmo que leva a cruz, leva a caldeira, outras vai outro coela ou coa campaíña, ou co escano. O que leva a cruz non pode mirar pra tras nin sabe-lo que pasa. Recibe os mandados sen que il saiba como. O que unha vez recibiu a cruz fica obrigado a levala todas as noites. Ben estea nun lugar ou noutro, chega a hora e ten que deixar todo e marchar á eirexa colle-la cruz. Unhas veces sinte que o chaman os defuntos; outras, sen que o chamen, empeza a sentir un desacougo, un formiguexo que non o deixa parar ata que vai cumpri-la obriga. ${ }^{19}$

O etnógrafo ourensán dálle a caracterización de Santa á Compaña e sinala que é unha crenza sobre o poder que teñen as almas do purgatorio de saír a penar os pecados, ademais de avisar da proximidade dunha morte. Atribúelle á lenda unha orixe cristiá, negando a posibilidade dun mito celta. E esa idea, estendida polo mundo rural galego, foi tolerada pola Igrexa católica.

Son menos comúns as versións da lenda recollidas na illa de Ons por Alonso Romero (I98I: 285-307). A que transcribo é dunha muller de 67 anos que asegura que a Compaña se ve moitas veces na illa e que «dá gusto mirar pra ela»:

A Compaña hai que vixiala de noite. Pola lus xa se conoce. A lus é encarnada coma o lume. Ela vén alta de todo, enriba de todo o mundo. Esa lumbrera é a Compaña. Dá un alumbrado que se mira como agora o día; mírase a illa en claro como agora o día; míranse os toxos, o monte, millor ca o que se mira agora. E despois desta lus vén outra pero máis pequena e baixiña; é unha lus branca, e despois vén todo o Acompañamento. Vén xente de toda clase: pequena, grande, neniños pequerrechiños, cans... Van vestidos coma nós. Míranse andar pola beira do mar na plaia de Melide. Van caladiños e moitos portan a caixa de defuntos, e detrás del sigue outra lus branca. E a Compaña deixa a caixa diante da casa onde vai morrer alguén. Aquí na illa mírase o Acompañamento moitas veces.

Como sucede noutras versións, a procesión chega precedida pola luz, mais a diferenza está na pormenorizada descrición dos cambios de luminosidade a medida que a procesión descende desde o aire á terra. A Compaña sae dun lugar escuro e nebuloso, pero a luz é moi clara «encarnada coma o lume» e logo ponse bran-

I9 «Din que aínda algúns que estaban en Castela, na sega, ou ocupados noutra cousa, viñan dalá todas as noites colle-la cruz». Se a persoa da cruz estaba entre un grupo, ninguén se daba conta de que marchara. 
ca. As estadeas visten como xente viva e, curiosamente, na Compaña van nenos de distintas idades e as estadeas levan varios cadaleitos que van deixando na porta da xente que vai morrer.

Non estraña a insistencia da informante na realidade dos feitos, o que estraña é a maneira de narrar a súa visión da Compaña. Está tan compracida na súa contemplación que semella unha visión epifánica, provocando no investigador este comentario: «Y lo decía con tal convencimiento que era imposible no creerla» (Alonso I98I: 286-87).

Un irmán da informante anterior dá unha versión menos elaborada da Compaña; el oe a chegada da procesión polo titilar das campaíñas e non pola luz que irradia:

Unha vez un home iba prá súa casa, alá pra o Centulo ${ }^{20}$ e sinteu tocar as campanillas. Era a Compaña e non fixo caso, e veu andar así un pouco pra diante e topou unha caixa de defuntos. Estaban tocando campanillas arredor da caixa e había moito xentío arredor. Un fulano da Compaña díxolle que por alí non se podía pasar. Entón tuvo que dar a volta e de alí ós tres días morreu a muller que vivía na casa. Morreu al librar. ${ }^{2 \mathrm{I}} \mathrm{E}$ xa non librou; morreu ela e mais o fillo (Alonso I98I: 29I).

As versións que seguen fóronme referidas en I998 en Baiona (Pontevedra) e en Vilar de Banzas, no concello da Serra de Outes (A Coruña), neste mesmo ano 20I9, por dúas anciás, de Io5 anos e de 98 anos. A de Baiona relata a aparición da Compaña como un suceso que lle contaron:

Indo para alá á Ghuardia de colle-lo arghaso, de ghañar unha peseta porque non había onde ghañar para comer, resulta que chegharon á mitá dun camiño e encontraron unha xente que viña con luses, de alí arriba, con velas. As mulleres ían unhas diante doutras, ou outras así ó par, ou como fora... Pero aquí adiante díxolle a aquelas almas, que disque eran almas do outro mundo que penaban porque non había muitas misas, non había quen resara, e esas cousas. Entonses díxolle aquí adiante, díxolle: «Por causa túa, por causa túa, eu que ía diante, que era a primeira que me iba salvar, teño que quedar atrás». Pra lle avisar a aquelas mulleres que iban falando, iban disindo así cousas... E perderon a Compaña, que lle chamaban a Compaña. E ela, que quedaba ahora de última: «Ahora por causa vosa teño, que... Eu que me iba salvar, teño que ir atrás e quedo de última. Sálvanse as que van diante i eu quedo así». Ela seghiu penando entonses. Despois foi cando se descubriu que eran as ánimas que andaban penando, que había toque de orasión; de mañán tocaban á orasión, resaban. Pero había xente tan abandonada que non resaba.

Non se nomea o suxeito da acción, a anciá inicia o relato co xerundio «indo pra a Guarda» vender o argazo (algas) e pon o verbo en terceira persoa de plural ('chegaron', 'encontraron'), polo que se refire a un grupo de mulleres entre as que non estaba ela. A informante comenta que na Compaña ía «xente que viña con luces de alí arriba, con velas». E ao dicir «alí arriba» sinalaba o mar cara ás illas

20 O lugar de onde baixa a Compaña que vén da aldea de Noalla, próxima ao Grove (Pontevedra).

2I 'Parir', 'dar a luz'. 
Cíes, de onde ao amencer chega a brétema mariña cando hai borrascas. A procedencia da Compaña dunha illa relaciona o relato cos referidos en Ons e coa posibilidade da súa base celta. A luz tamén aquí «cumpre unha función dobre: é o aviso da chegada da Compaña, márcalle a ruta que vai seguir e ilumina o escenario» (Alonso I98I: 287). No relato da señora de Baiona parece que só van estadeas con velas, non se fala de cruz nin doutros obxectos litúrxicos que van noutras versións. Unha das estadea protesta por perder a dianteira falando coas mulleres que van á Guarda, dando a entender que as que van nos primeiros lugares son as primeiras en saír do purgatorio. E a narradora conclúe que as almas saen a penar porque non se reza abondo por elas, deixando de manifesto a mestura de referencias á cultura celta e á fe católica.

A muller de Outes insistía en que ela nunca vira a Compaña porque, dicía, só certas persoas podían vela, que coñecía o caso duns mozos que se atoparan con ela que se contaba na aldea de Vilar:

Dous mozos ían unha noite neboenta por un camiño. Un oe unha especie de murmurio xordo [a señora reproduce o son como bisbexando] e ve luces ao lonxe que se achegan entre a néboa como flotando sobre o camiño. «É a Compaña!», dille ao amigo. Pero el non ve nada por máis que o intenta. O que a está vendo, mándalle que poña un pé enriba dun seu mirando de fronte onde el lle di. Faino e acabou vendo vir a Compaña.

Este texto mostra a vitalidade da crenza de que só algunhas persoas teñen a capacidade de ver a Compaña e como se facía para poder vela da que fala Antonio Fraguas (I973: IO2). Quen, a diferenza da señora que non coñece a razón de que iso suceda así, o etnógrafo sabe que só poden ver a Compaña as persoas que recibiron os Santos óleos e, de non recibilos, quen queira vela no momento que pasa debe descalzarse e poñer o pé dereito sobre o de quen a está vendo.

Son moitas as versións rexistradas desta lenda, relatos diferentes creados pola mente humana na escuridade dos claro-escuros e nun espazo xeográfico que propicia o misterio. Nunhas, a Compaña vén de lonxe luminosa e etérea saíndo da brétema, en silencio ou detectada polo murmurio dos rezos e da campaíña, mais sen achegarse a xente. E, noutras, as estadeas saen pola noite das tumbas e andan por camiños da parroquia levando unha cruz (estandarte), un caldeiro de auga bendita e velas acesas ou un farol avisando da morte dun veciño e achegándose á xente que atopan para darlle a cruz ou unha vela. E, sen ter feita unha análise comparativa entre as versións que coñezo, creo que a diferenza entre a percepción sensorial de ver a Campaña dunha maneira ou doutra pode estar en relación coa amplitude de visión do mar fronte á falta de perspectiva da vexetación dos camiños do interior. ${ }^{22}$

\section{Por que chamamos lendas ás crezas nas ánimas}

Como se sabe, o termo lenda nace na Idade Media para denominar relatos sobre a vida de santos, santas ${ }^{23}$ e de personaxes que viviron feitos sobrenaturais ou heroi-

22 Lison Tolosana (I998) presenta e analiza un número grande de relatos orais mais non estuda a variante do lugar de orixe dos informantes en relación ao tipo de versión contada.

23 O termo procede da obra Legenda Aurea do frade dominico Jacobus de la Voragine, no século XIII procedente do participio de futuro do verbo latino legere, «o que se debe ler». É 
cos. Mais, baseándose na veracidade dos feitos que a xente das comunidades rurais lle daba á lenda, desde fins do século XIX, os folcloristas definiron a lenda fronte ao conto, caracterizado por ser un relato irreal, de ficción; e, polo tanto, a lenda sería un relato contado como un suceso real. Porén, no ámbito da oralidade, as historias non se someten a normas teóricas de xénero nin a denominacións literarias, son as e os informantes quen lles dan nome ao que contan seguindo a tradición. E, aínda que os (as) folcloristas adoitan respectar a concepción popular dos etnotextos, a teoría pode coincidir ou non coa oralidade, dado que os nomes «son con frecuencia 'estados' en los que vive y se trasmite una narración, más que un aspecto sustancial a la misma», como di Díaz de Viana (2008: 25). Para quen traballamos na narrativa oral non é infrecuente escoitar un conto folclórico como lenda, e viceversa, e así o expresa a folclorista Nicole Belmont (I982: 2I9):

Dans ce jeu, dans ce va-et-vient entre croyance et réalité, entre imaginaire et réel, la légende se forme et se transforme, vit d'une vie qui lui est propre, se transmet (selon des lois qui ne sont sans doute pas tout à fait celles de la transmission du conte, dont le statut est plus univoque); sans doute, meurt-elle lorsque disparaît la croyance génératrice qui lui avait donné naissance et lui fournissait impulsion et dynamisme.

Insistindo na mesma idea, Josiane Bru (20I0: 5) fala da 'porosidade' que se produce na oralidade entre os xéneros narrativos:

Associant un épisode introductif d'un bon nombre de contes et le «style » ou le ton de la légende (implication du narrateur et localisation précise), le récit fondé sur la croyance au surnaturel témoigne que la porosité des mondes si présente dans le conte merveilleux est une réalité dans les représentations populaires.

Eu mesma teño a experiencia de escoitar contos, aos que as (os) informantes se referían como sucesos, poñéndose eles como suxeitos ou dicindo: «Bueno, isto pasoulle á irmá da miña avoa», «o que lle vou contar non é conto, sucedeu aquí, no alto do monte...» ou algo semellante. Os nosos antepasados crían e convivían co máxico como algo natural no ámbito cotián. E, firmes crentes na posibilidade da presenza das ánimas no seu mundo, non dubidaban da veracidade deses relatos por fantásticos que nos parezan. O seu discurso construíase con retórica de convicción sobre a verdade dos feitos, para mostrar que non son contos.

Lenda e crenza son termos válidos para denominar este tipo de historias fantásticas protagonizadas por xente que cre na posibilidade de comunicarse cunha ánima do Alén. Ambos conceptos veñen ser sinónimos para denominar relatos contados como experiencia vivida, da propia narradora (narrador) ou por algún achegado. E, desde o século XIX, etnógrafos e folcloristas danlle unha ou outra denominación. O folclorista sueco Carl Willelm von Sydow (I879-I952), cuxa obra descoñezo, propón o uso dun tercer nome tirado do imperativo latino 'memorate' para denominar este tipo de relatos que non parece ter callado.

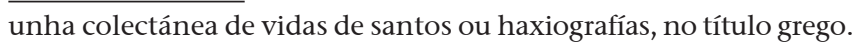




\section{Coda}

Na definición de Martos Núñez (I997: III) as lendas «son la expresión del imaginario de unha comunidad, la radiografía —en el sentido de mostrar el 'interior a través de palabras, imágenes, ritos...-». E que son se non as nosas historias sobre a volta das ánimas? Non podemos poñer en dúbida de que, chamémoslles crenzas ou mitos, as historias dos mortos representan a expresión do imaxinario colectivo ante o misterio da morte. Tampouco podemos dubidar de que, malia o que nós pensemos sobre estas historias, a xente do rural contounas sempre como sucesos, non como contos fantásticos. E hai máis dun século que Le Braz e Paul Sébillot ${ }^{24}$ consideraron lendas etnotextos bretóns semellantes aos nosos de ánimas; como fixo o folclorista noruegués Reidar T. Christiansen (I958) inserindo as lendas de ánimas na serie 4000-4050 «Legends of the Human Soul, of Ghosts and Revenants» do seu catálogo The Migratory Legends. Así pois, cómpre darlles o nome de lenda, que xa utilizaran os etnógrafos galegos Jesús Taboada Chivite e Antonio Fraguas alternando con crenza, aos relatos de ánimas. E a este tipo de lendas poderíase engadir o adxectivo 'míticas', como propón Pinto-Correia (I993: 67) diferenciándoas así doutros tipos.

Son demasiadas as lendas galegas sobre defuntos e ánimas para poder tratalas todas, algunhas de gran difusión como a misa nocturna ou a viaxe das ánimas a San Andrés de Teixido. Nun novo artigo volverei sobre esas e outras.

\section{Referencias}

Alonso Romero, Fernando (I98I): «Los orígenes del mito de la Santa compaña de las islas de Ons y Sálvora». Cuadernos de Estudios Gallegos vol. 32: 285-305.

- (2009): El mundo de la muerte en Galicia y en el folclore del norte de Europa. Vigo: AGCE.

BESANÇON, Dominique (I996): Anatole Le Braz et «La Légende de la Mort ». Rennes: Terre de Brume Éditions.

BogGS, Ralph (I993) [I930]: Index of Spanish Folktales. Helsinki: Folklore Fellows Communications [Segunda edición en I993].

Borrow, George (1843): The Bible in Spain. London: John Murray. Albemarle Street.

- (I993): Viaxe por Galicia. Tradución, limiar e cronoloxía da viaxe por terras galegas que aparece no libro anterior de Salvador García Bodaño. Vigo: Xerais.

BRAgA, Teófilo (I885): O povo portuguez nos seus costumes, crenças e tradições, vol. 2. Livraria Ferreira <https://archive.org/details/opovoportugueznoobraggoog> [data de consulta: xullo de 20I9].

BRU, Josiane (20IO): «La légende comme récit bref et les limites du conte ». Pode consultarse en Hal. Archives-ouvertes: <https://hal-univ-tlse2.archives-ouvertes.fr/hal-oII48973> [data de consulta: xullo de 20I9].

24 Recolle lendas deste tipo en varios dos seus libros sobre o folclore bretón, en especial en Légendes locales de la Haute-Bretagne, publicado en 1899. 
Camarena, Julio; Maxime Chevalier (2003): Catálogo tipológico del cuento folclórico español. Cuentos religiosos. Tomo III. Alcalá de Henares (Madrid): Centro de Estudios Cervantinos.

CARdigos, Isabel; Paulo Correia (20I5): Catálogo dos contos tradicionais portugueses (com as versoes análogas dos paises lusófonos), vol. 2. Santa Maria da Feira: Universidade do Algarve / Edições Afrontamento.

Corominas, Joan; José A. PAScuAL (I98I): Diccionario crítico etimológico castellano e hispánico, 6 vols. Madrid: Gredos.

CHRISTIANSEN, Reidar Thoralf (I958): Migratory Legends, a proposed list of types with a systematic catalogue of the Norwegian variants. Folklore Fellows Communications, I75. Helsinki: Suomalainen Tiedeakatemia.

CUBA, Xoán Ramiro (20IO): «Ánimas, aparecidos e mortos en compaña na tradición galega». En Actas das III Xornadas de Literatura de tradición oral. Mitoloxía da morte: Agoiros, ánimas e pantasmas. Lugo: Asociación de Escritores en Lingua Galega (ASPG), p. 8I-93.

Cuba, Xoán Ramiro; Antonio Reigosa; Xosé Miranda (I999): Diccionario dos seres miticos galegos. Vigo: Xerais.

DELPECH, François (I989): «La légende: réflexions sur un colloque et notes pour undiscours». En Jean Pierre ETIENVRE (coord.) (I989): La leyenda: antropología, historia, literatura: Actas del Coloquio celebrado en la Casa de Velázquez. Madrid: Casa de Velázquez y Universidad Complutense, p. 29I-305.

DEZINGER, Enrique (I96I): El magisterio de la Iglesia. Manual de símbolos, definiciones... Barcelona: Herder [Versión española da 3ıа edición do Henrici Denzinger Enchiridion Symbolorum. Friburgo de Brisgovia: Herder, I958].

DíAz ViAnA, Luis (2008): Leyendas populares de España. Madrid: La Esfera de los Libros.

ÉveIllard, James; Patrick HuCHet (2004): Croyances et superstitions en Bretagne. Rennes: Éditions Ouest-France.

Fraguas, Antonio (I93I a): «O culto ós mortos». Nós núm. 87 (I5 de marzal): 42-46.

- (г93І $b$ ): «Do folk-lore de Armeses-Listanco». Nós núm. 96 (I5 de Nadal): 22 I227.

- (I973): La Galicia insólita. A Coruña: Editorial Librigal.

- (I986): «O mundo das ánimas». Encrucillada núm. 49 (setembro-outubro): 5-22.

- (I990): La Galicia insólita. Tradiciones gallegas. Sada (A Coruña): Ediciós do Castro. Segunda edición revisada da de I973.

LE BrAZ, Anatole (I893): La légende de la mort. París: Honoré Champion. Versión en rede.

Lembranzas de Vellos (I993): Aula da Terceira Idade de Vigo. Santiago de Compostela: Xunta de Galicia. Consellería de Traballo e Servizos Sociais.

Lisón TolosAnA, Carmelo (I998): La Santa Compaña. Fantasías reales. Realidades fantásticas (Antropología cultural de Galicia IV). Madrid: Ediciones Akal. 
MARiño Ferro, Xosé Ramón (I995): Aparicións e Santa Compaña. Pontevedra: Edicións do Cumio.

MARTos NúÑEz, Eloy (I997): «Hacia una geografía legendaria de la península: de la Santa compaña al cazador negro». En Enrique BARCiA (ed.): Cuentos y leyendas de España y Portugal / Contos e lendas de Espanha e Portugal. Mérida (Badajoz): Junta de Extremadura, p. IOI-II3.

MAURE Rivas, Xulián (2006): Para unha escriptoloxía do galego. A Coruña: Fundación Barrié de la Maza.

Neves Casinha Nova, Maria Manuela (2OI2): «As lendas do sobrenatural da Região do Algarve». Ramo de Doutoramento em Estudos de Literatura e Cultura (literatura oral e tradicional). Faculdade de Letras da Universidade de Lisboa. Dispoñible na rede.

NoIA, Camiño (20IOa): Catálogo tipolóxico do conto galego de tradición oral. Vigo: Servizo de Publicacións da Universidade de Vigo.

— (20Iob): «Representación da morte na narrativa oral». Ver Cuba. Actas das III Xornadas..., p. 65-80.

OliveirA, Ataíde (s/d): Monografia de Estombar - Concelho de Lagoa. Faro (Algarve): Foco Editora.

Pinto-Correia, David (I993): «Os Géneros da Literatura Oral Tradicional. Contributo para a sua Classificação». Revista Internacional da Língua Portuguesa núm. 9 (julho): 63-69.

Pedroso, Consiglieri (I880): Contribuições para uma mythologia popular portugueza. Porto: Imprensa Commercial. Segunda edición en I988 en Lisboa: Publicações Dom Quixote.

Posse, Juan Antonio (1984): Memorias del cura liberal D. Juan Antonio Posse. Madrid: Akal.

QuinTÁNS SuÁREZ, Manuel (2006): O Outro Mundo na cultura popular galega. Santa Comba (A Coruña): tresCtres.

RisCO, Vicente (I962): «Etnografía. Cultura espritual». En Ramon OTERo PEDRAyo (director): Historia de Galiza. A Terra. O home, vol. I. Buenos Aires: Editorial Nós, p. 255-777.

RODRÍGuez López, Jesús (I993): Supersticiones de Galicia y preocupaciones vulgares. Salamanca: Editorial Aliviadoiro, ıoa edición. A primeira é de i895.

SARMiENTO, Martín Fr. (I973): Catálogo de voces y frases gallegas. Edición y estudio por J. L. Pensado. Salamanca: Secretariado de Publicaciones de la Universidad.

SÉBILlot, Paul (I983): Le folklore de France. La mer. Paris: Éditions Imago. Primeira edición en I904.

TABOADA, Jesús (I96I): Folklore de Verín. Las creencias y el saber popular. Ourense: Imprenta La Región. 